\title{
Completion of 1:500 000 reconnaissance mapping in the Precambrian of the Evighedsfjord - Søndre Strømfjord - Itivdleq region, southern West Greenland
}

\author{
Jan H. Allaart and Stig Bak Jensen
}

The three years reconnaissance mapping programme for the 1:500 000 map sheet Frederikshåb Isblink - Søndre Strømfjord (Allaart et al., 1977, 1978) was completed during the 1978 summer season. This summer's activity was concentrated in the area between Evighedsfjord and the northern boundary of the map sheet at latitude $66^{\circ} 45^{\prime} \mathrm{N}$, and west of longitude $51^{\circ} 30^{\prime} \mathrm{W}$ (fig. 26). The area north-east of the Sukkertoppen Iskappe was reconnoitred during the summer of 1969 (Escher et al., 1970). The area around Itivdleq and further north has been mapped more recently by geologists from the University of Liverpool under the direction of J. Watterson (1974). The mapping team in 1978 comprised two geologists based on the GGU cutter J. F. Johnstrup; periodic reconnaissance with Jet Ranger and Bell 204 helicopters was undertaken. The guidance of J. Watterson in the area around Itivdleq and Kangerdluarssuk fjords was greatly appreciated.

\section{Rock units}

Supracrustal rocks. Rocks of supracrustal origin comprise mainly amphibolite with intercalations of metasedimentary rocks and lenticular bodies of ultrabasic olivine-rich rocks. The amphibolites usually contain clinopyroxene and are often hypersthene-bearing in granulite facies and retrogressed granulite-facies regions. In the metasedimentary rocks garnet and biotite are generally the main mafic minerals, while sillimanite is of frequent occurrence. The supracrustal units form either trains of inclusions in the gneisses, traceable over considerable distances, or continuous intricately folded horizons demonstrating the complex structural development of the gneisses. In some localities masses of supracrustal rocks are strongly agmatised. The amphibolites, metasedimentary rocks and associated rock types are believed to represent units of Malene supracrustals ( $>3000$ m.y. old). A probable exception is an occurrence of supracrustals just south of the Sarfartôq valley (Diggens \& Talbot, 1974), which might be much younger and transported from the north by Nagssugtoqidian thrusting.

Metamorphosed anorthosites and leucogabbro. In some areas of the region the gneisses contain trains of inclusions of leucogabbro or anorthositic rocks. Occasionally these can be followed over long distances, e.g. along the south-east side of Evighedsfjord and at the southern shore of Itivdleq.

Granulite facies gneisses. Nebulitic hypersthene gneisses are exposed north-east of Sukkertoppen Iskappe (Escher et al., 1970) and between Kangâmiut and Kangerdluarssuk fjord. These constitute the continuation of the Archaean Sukkertoppen granulites (Bridgwater et al., 1976) 2890 \pm 60 m.y. old (Black et al., 1973).

Around Itivdleq some isolated areas of granulite facies and amphibolite facies gneiss occur as older lacunae or 'augen' in the region affected by Nagssugtoqidian deformation.

Amphibolite facies gneisses. In the northern part of the region amphibole- and biot- 


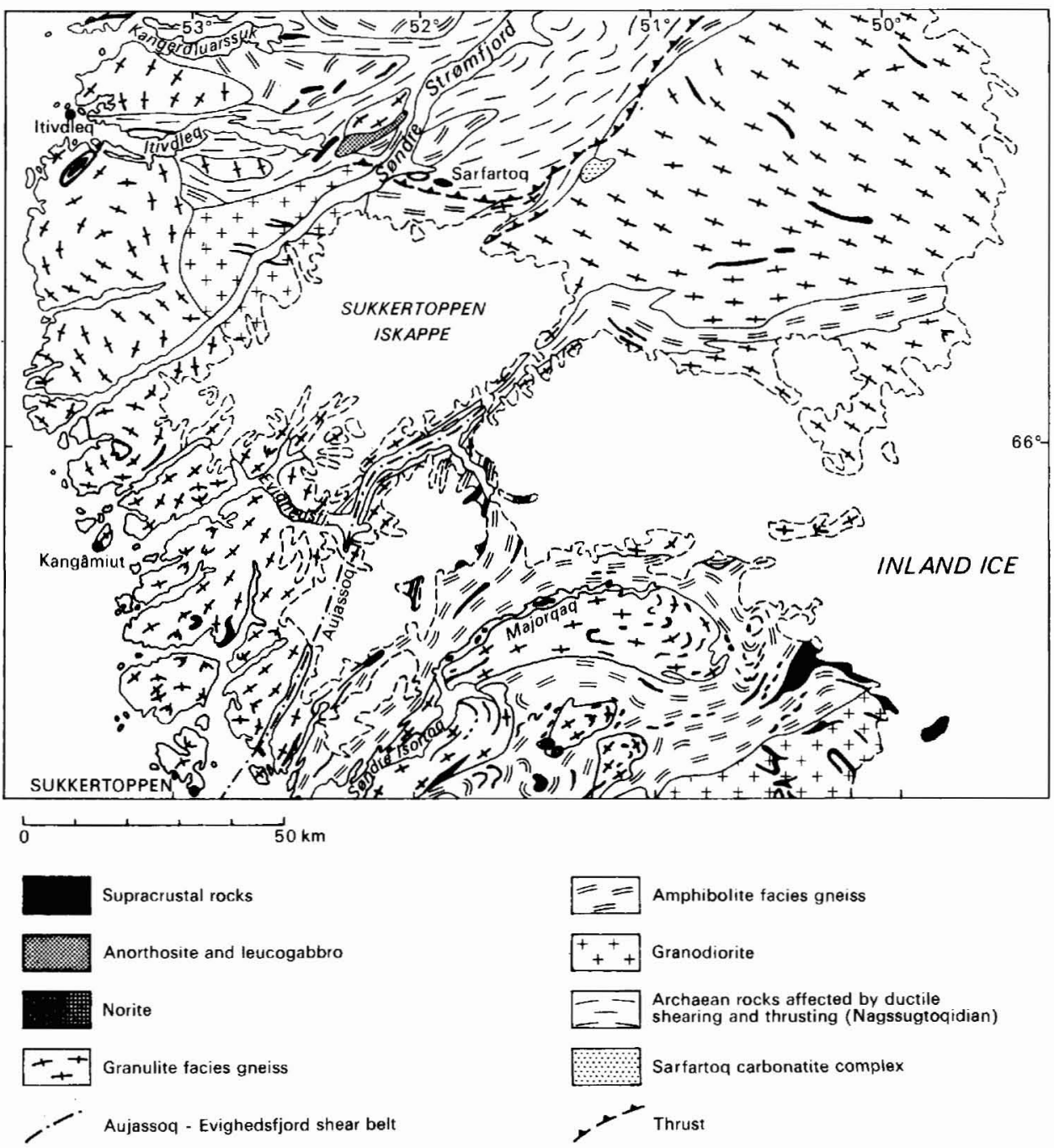

Fig. 26. Geological sketch map of the Sukkertoppen - Søndre Strømfjord region, West Greenland.

ite-bearing quartzo-feldspathic gneisses occur. These vein and agmatise supracrustal and anorthositic rocks. The gneisses are thought to correspond to the 2800-3000 m.y. Nuk gneisses.

Granodiorite. A body of granodiorite occurs along both sides of Søndre Strømfjord, immediately north-west of Sukkertoppen Iskappe. In the western part of the body the granodiorite is non-foliated and medium- to coarse-grained. More to the east foliation is commonly developed and the rock is medium-grained. Amphibolite horizons with a dominantly east-west trend are common in the granodiorite. 


\section{Belts of ductile shearing in the Archaean gneisses}

In some areas the granulite facies gneisses are downgraded in belts of ductile shearing to amphibolite facies gneisses with very strong deformational fabrics. These belts range in width between a few centimetres and several kilometres. A few important ductile shear belts with transcurrent movement occur in the region. The south-easternmost example is the Aujassoq-Evighedsfjord shear belt (fig. 26). Its central part consists of fine-grained mylonitic gneiss exposed on islands north-east of Sukkertoppen. More to the north along the inner part of Evighedsfjord the trend of the shear belt swings from NNE to NE and still further north appears to die out towards a large area of granulite facies gneisses. Locally in the Aujassoq-Evighedsfjord shear belt relict lenses or zones of sheared rock occur which are still hypersthene-bearing (granulite facies). These alternate with zones of sheared rock in amphibolite facies.

Along the fjords Itivdleq and Kangerdluarssuk two other important shear belts of strongly deformed gneisses in amphibolite facies occur. These trend E-W and cross-cut the older structures in the granulite facies block, as has been shown by geologists from the University of Liverpool (see also Bridgwater et al., 1973a). The eastern continuations of the shear belts near Søndre Strømfjord have been overprinted by later ductile thrusting.

\section{Kangâmiut dykes}

The Kangâmiut dyke swarm (Ramberg, 1948) was mapped by Escher et al. (1970). There are two sets of dykes, an earlier E-W trending generation and a later NNE to NE-trending generation (Bridgwater et al., 1973b; Escher et al., 1975, 1976). Around Sukkertoppen the frequency of the dykes is not more than 1 or 2 per cent. Between Kangâmiut and the mouth of Søndre Strømfjord densities are considerably higher, reaching up to 7 per cent in some areas. Between Sarfartôq and Sukkertoppen Iskappe just south of the front of late Nagssugtoqidian ductile thrusting densities of 15 per cent have been estimated.

In Evighedsfjord the Kangâmiut dykes have a regular NE trend and do not show any tendency to adapt their courses to the trend of the shear belt. The form of the dykes is also regular, i.e. the dykes have usually straight and parallel contacts. This behaviour is in striking contrast to the behaviour around the fjords Itivdleq and Kangerdluarssuk, where, when entering the shear belts, the Kangâmiut dykes change their trend from NE to E-W. Moreover their regularity disappears and they develop consistently pinch and swell forms which, as demonstrated to us in the field by $\mathbf{J}$. Watterson, are not the result of later deformation, but a primary intrusive phenomenon which took place in hot country rocks. The dyke rocks themselves contain much garnet, and are brown. The behaviour of the dykes apparently suggests that the ductile transcurrent shearing and dyke intrusion were close to each other in time.

\section{Later ductile thrusting}

A later phase of deformation (ductile thrusting) mainly took place in the area east of the inner part of Søndre Strømfjord (fig. 26), post-dating the Kangâmiut dykes. The general result of the deformation is reorientation of the originally discordant dykes and the gneiss 
foliation towards parallelism, but here and there the dykes are also folded. Surprisingly, this ductile thrusting is nowhere accompanied by migmatisation of the dykes by the surrounding gneisses, the only sign of mobility being boudinage of the dykes. Although the area where ductile thrusting has taken place is rather broad, on the west side of Søndre Strømfjord there are much rarer signs of ductile thrusting. In this area the earlier ductile shear belts at Itivdleq and Kangerdluarssuk surround augen of granulite facies gneiss and gneisses partly retrogressed to amphibolite facies but with undeformed Kangâmiut dykes. At a few localities folding of Kangâmiut dykes shows that the later thrust movements have only locally been active. South of the anorthosite augen east of Itivdleq there is a thin ductile thrust which is the continuation of the thrust zone from Sarfartôq. This thin thrust appears to die out towards the south-west and does not continue as far as Itivdleq.

We have the impression that in the area east of the inner part of Søndre Strømfjord ductile thrusting is also not everywhere of high intensity. It is very strong around Sarfartôq valley where the Kangâmiut dykes are thoroughly amphibolitised and parallel to the gneiss foliation. In the area north of the valley ductile thrusting has been weaker and of variable intensity.

\section{Pseudotachylites}

Ultramylonites and pseudotachylites were observed throughout the region north of Evighedsfjord, and are thought to be related to Nagssugtoqidian deformation. Some are found cross-cutting Kangâmiut dykes.

\section{Carbonatite and kimberlite dykes}

In Søndre Strømfjord area, thin, rusty, discordant carbonatite dykes occur occasionally. These are thought to be genetically connected to the carbonatite complex east of the fjord (Secher \& Larsen, 1978). Thin kimberlite dykes occur in the Itivdleq-Kangerdluarssuk area and a few have also been found at Søndre Strømfjord.

\section{References}

Allaart, J. H., Jensen, S. B., McGregor, V. R. \& Walton, B. J. 1977: Reconnaissance mapping for the 1:500 000 map sheet in the Godthåb-Isua region, southern West Greenland. Rapp. Grønlands geol. Unders. 85, 50-54.

Allaart, J. H., Friend, C. R. L., Hall, R. P., Jensen, S. B. \& Roberts, I. W. N. 1978: Continued 1:500 000 reconnaissance mapping in the Precambrian of the Sukkertoppen region, southern West Greenland. Rapp. Grønlands geol. Unders. 90, 50-54.

Black, L. P., Moorbath, S., Pankhurst, R. J. \& Windley, B. F. 1973: ${ }^{207} \mathrm{~Pb} /{ }^{206} \mathrm{~Pb}$ whole rock age of the Archaean granulite facies metamorphic event in West Greenland. Nature Phys. Sci. 244, 50-53.

Bridgwater, D., Escher, A., Nash, D. F. \& Watterson, J. 1973a: Investigations on the Nagssugtoqidian boundary between Holsteinsborg and Kangâmiut, central West Greenland. Rapp. Grønlands geol. Unders. 55, 22-25.

Bridgwater, D., Escher, A. \& Watterson, J. 1973b: Tectonic displacements and thermal activity in two contrasting Proterozoic mobile belts from Greenland. Phil. Trans. R. Soc. Lond. A 273, 513-533. 
Bridgwater, D., Keto, L., McGregor, V. R. \& Myers, J. S. 1976: Archaean gneiss complex of Greenland. In Escher, A. \& Watt, W. S. (edit.) Geology of Greenland, 18-75. Copenhagen: Geol. Surv. Greenland.

Diggens, J. \& Talbot, C. 1974: Nagssugtoqidian supracrustal metavolcanic rocks of Sarfartûp nunâ, Søndre Strømfjord, central West Greenland. Rapp. Grønlands geol. Unders. 65, 37-39.

Escher, A., Escher, J. \& Watterson, J. 1970: The Nagssugtoqidian boundary and the deformation of the Kangâmiut dyke swarm in the Søndre Strømfjord area. Rapp. Grønlands geol. Unders. 28, 21-23.

Escher, A., Escher, J. C. \& Watterson, J. 1975: The reorientation of the Kangâmiut dike swarm. Can. J. Earth Sci. 12, 158-173.

Escher, A., Sørensen, K. \& Zeck, H. P. 1976: Nagssugtoqidian mobile belt in West Greenland. In Escher, A. \& Watt, W. S. (edit.) Geology of Greenland, 76-95. Copenhagen: Geol. Surv. Greenland.

Ramberg, H. 1948: On the petrogenesis of the gneiss complexes between Sukkertoppen and Christianshaab, West-Greenland. Meddr dansk geol. Foren. 11, 312-327.

Secher, K. \& Larsen, L. M. 1978: A new Phanerozoic carbonatite complex in southern West Greenland. Rapp. Grønlands geol. Unders. 90, 46-50.

Watterson, J. 1974: Investigations on the Nagssugtoqidian boundary in the Holsteinsborg district, central West Greenland. Rapp. Grønlands geol. Unders. 65, 33-37.

\title{
Observations on the late Archaean Qôrqut Granite, Qôrqut, Godthåbsfjord, southern West Greenland
}

\author{
A. D. M. Burwell and C. R. L. Friend
}

The Qôrqut Granite is an elongate body, $50 \mathrm{~km}$ long and up to $18 \mathrm{~km}$ wide, emplaced in the core of a broad NNE-SSW trending antiform (McGregor, 1973; Bridgwater et al., 1976). In the central part of the pluton are large areas of homogeneous granite but elsewhere the body consists of a complex association of granite and migmatised enclaves. The roof zone of the granite consists of gently-dipping sheets of granite and pegmatite separated by rafts of country rock, the latter retaining their original orientation well down into the main body of the granite. In the southern part of the pluton, two phases of granite may be recognised, an early biotite-rich phase and a later, more leucocratic, biotite-poor phase.

This report concerns the northern part of the Qôrqut Granite in the area north of Qôrqut. The main body of the intrusion consists of irregular, interconnected sheets of granite which are separated by sub-rectangular blocks of country rock (dominantly Amitsoq gneiss). The latter, which may attain lengths of several hundred metres, have sharp margins and normally contain irregular veins and pods of pegmatite. The granite sheets frequently contain small (1-5 m diameter), migmatised enclaves of country rock, the degree of migmatisation decreasing with proximity of the enclave to the margin of the enclosing granite sheet. Schlieren textures are common in these enclaves, ophthalmitic textures rare. Most of the enclaves are of relatively local origin but rare examples occur of biotite-rich, partial melt residues, prob- 